\title{
ChikDenMaZika Syndrome: the challenge of diagnosing arboviral infections in the midst of concurrent epidemics
}

\author{
Alberto E. Paniz-Mondolfi, ${ }^{1,2}$, Alfonso J. Rodriguez-Morales ${ }^{3,4,5,6^{*}}$, Gabriela Blohm, Marilianna Marquez ${ }^{1}$ \\ and Wilmer E. Villamil-Gomez $3,6,8,9$
}

Arthropod-borne viruses are becoming and increasing threat worldwide, especially in the New World, which has recently witnessed an unprecedented outburst of Arboviral outbreaks [1-4], such as the recent and ongoing chikungunya (CHIKV) [1] and Zika (ZIKV) [2] epidemics throughout the Pacific and the Americas. These emerging viral infections are largely due to a number of factors such as climate change [5-7], ever-increasing trends towards urbanization and growing travel and commercial exchange activities [8-12]; which have led to a spillover of these pathogens from their naturally occurring sylvatic niches and reservoirs into susceptible urban settings and newly unexposed geographic areas [13-16].

Other arbovirus such as yellow fever (YFV) and dengue (DENV) [6, 17], have been circulating for longer in the American continent exhibiting endo-epidemic cycles influenced by a number of enabling drivers such as poor socioeconomic conditions, climate variations, migration from rural to urban locations, among others $[3,4,6,7$, 11-13, 17]. The complex but at the same time suitable eco-epidemiological conditions of tropical and subtropical regions has privileged the persistence of arboviruses by providing an ideal blend in terms of vector usage and specificity as well as an ample host range. Actually, newly introduced arboviruses in the New World seem to be smoothly transitioning from their epidemic effervescence into endemic levels of transmission revealing an increased potential for adaptation $[1-3,16]$.

Arboviruses in Latin America include a number of pathogens belonging to different families such as the Flaviviridae (DENV and ZIKV) [3, 18], Togaviridae (CHIKV

\footnotetext{
*Correspondence: arodriguezm@utp.edu.co

${ }^{4}$ Public Health and Infection Research Group, Faculty of Health Sciences,

Universidad Tecnologica de Pereira, Pereira, Risaralda, Colombia

Full list of author information is available at the end of the article
}

and MAYV) [16, 19-21], and Bunyaviridae (Oropouche virus, OROV) [22] just to name a few; with their biologic behavior and pathogenicity exhibiting distinct features but also great similarities. In particular, for ZIKV, the fact that this virus along with its recent introduction has also found a naïve population with no pre-existing endemic cycles in the region, appears to have pressed for the appearance of new variants with an increased pathogenic potential such as recently observed in the evolving epidemic with a disproportionate number of atypical clinical manifestations and complications not seen before elsewhere $[2,9,23,24]$.

Although $80 \%$ of cases are asymptomatic, symptoms of ZIKV classically include mild or no fever, pruriginous maculopapular rash, conjunctivitis, arthralgia and myalgia, headache, malaise and fatigue (Table 1) [3, 25]. Notably, most of these symptoms can easily be confused with those of CHIKV, MAYV and DENV infections with a high chance of misdiagnosing such cases especially during early clinical stages, thus posing a significant diagnostic challenge amongst these arboviral-like illnesses (Table 1) [3, 25]. Differentiation on clinical grounds alone is often a very difficult task and requires a high degree of experience and clinical insight, despite the occurrence of distinct signs and symptoms such as focal joint edema of distal aspects of the limbs in ZIKV, meningism in OROV and retro/orbital pain and hemorrhagic diathesis in DENV (Table 1) [3, 25].

Moreover, clinical findings and differentiation among arboviral infections becomes a more complicated task when dealing with special populations such as pregnant women and children, due to their tendency to develop perinatal complications, particularly in CHIKV and ZIKV infections [26, 27].

In addition, cocirculation and coinfection with different arboviruses is becoming a common phenomenon 
Table 1 Main clinical findings in the ChikDenMaZika Syndrome $[3,25]$

\begin{tabular}{lllll}
\hline Clinical findings & \multicolumn{4}{l}{ ChikDenMaZika Arboviruses } \\
\cline { 2 - 5 } & CHIK & DEN & MA & ZIKA \\
\hline Fever & +++ & ++++ & ++++ & $++/ 0^{\mathrm{a}}$ \\
Myalgia/arthralgia & ++++ & +++ & +++ & ++ \\
Edema in limbs & 0 & 0 & 0 & ++ \\
Maculopapular rash & ++ & ++ & ++ & $+++^{\mathrm{b}}$ \\
Retro-ocular pain & + & ++ & ++ & ++ \\
Conjunctivitis, non-purulent & + & 0 & 0 & +++ \\
Lymphadenopathies & ++ & ++ & + & + \\
Hepatomegaly & ++ & 0 & + & 0 \\
Leukopenia/thrombocytopenia & ++ & +++ & ++ & $0 /+^{\mathrm{c}}$ \\
Hemorrhages & + & +++ & 0 & $0 /+^{\mathrm{c}}$ \\
\hline
\end{tabular}

Italics indicates for which of the arboviruses is the highest frequency of the clinical finding

${ }^{a}$ Depends on geography and phylogeny of the virus, in some areas patients do not present fever

b Pruriginous (mild to severe)

c In some cases these findings have been reported [2]

with cases reported from Africa (Nigeria and Angola, where an epidemic of YFV is ongoing, with imported cases to other continents) [28-30], the Caribbean (Haiti) [31], South America (Brazil and Colombia) [18, 32], and the Pacific (New Caledonia) [33]. Also, cases of coinfection with other endemic pathogens such as malaria (still a public health threat in areas of South East Asia and Latin America) [28], as well as other viral illnesses such as HIV are being increasingly reported [34, 35]. The broad range of possible coinfecting agents and the non-specific signs and symptoms at the initial stages of infection complicate even more the diagnostic approach to these cases, beyond the clinical aspects, implying as well the needs for the so called multiplex diagnostic tools [36].
Interestingly, confounding diagnosis between pathogens exhibiting similar clinical features and common geographical and epidemiological grounds, is not an uncommon scenario. For example, in several Asian countries were hepatorenal syndrome causing-hantavirus is endemic, there is usually a significant overlap of symptoms with cases of leptospirosis and infection by the scrub-typhus causative agent Orientia tsutsugamushi. Given the similar clinical features and the variable but notable immune-reactivity to these agents revealed by seroepidemiological studies, the term "Lepthangamushi" was adopted to describe this overlapping clinical syndrome [37].

As a result of our field work in South America [3, 4, $8-12]$, and in order to establish an effective clinical pattern recognition approach and diagnostic management strategy, in cases of infections suggestive of arthropodborne viruses, we have coined the term "ChikDenMaZika syndrome" which groups the major causative players in our region (CHIKV, DENV, MAYV and ZIKV) (Fig. 1), as a mnemonic rule to include in our list of differentials at the time of diagnosis. Nevertheless, it is essential for clinicians to always keep in mind the other look-alike entities that commonly occur endemically in their areas of practice, such as other viral infections like parvovirus B19, enteroviral exanthems, adenovirus, rubella, measles; bacterial infections like rickettsiae, Q fever, leptospirosis, ehrlichiosis and Streptococcus; as well as parasitic disease such as malaria and acute Chagas disease [38-43].

Efforts should focus on the necessity to contain the ongoing concurrent epidemics (Fig. 1) and to maintain strict and continued surveillance programs to monitor the spread of these viruses as well as the introduction of newly emergent pathogens $[3,13,16]$. In the field as well as in low-income and remote areas, clinicians should take into consideration the overlapping clinical features shared amongst these agents as well as the possibility

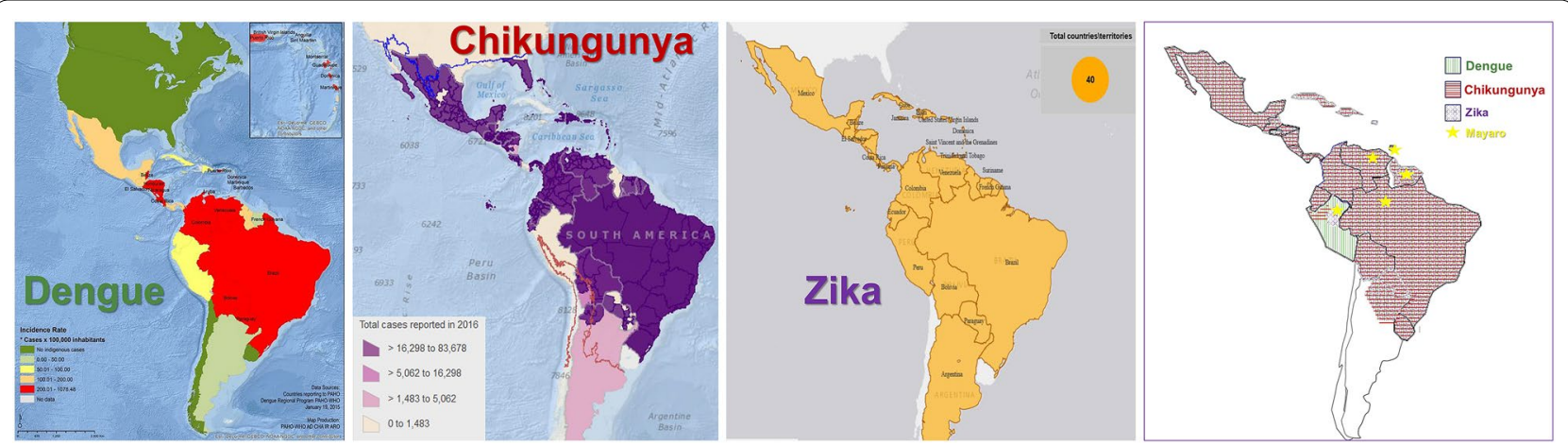

Fig. 1 Reported distribution of DENV, CHIKV, ZIKV and MAYV in Latin America, based on PAHO and review of literature 
of co-infection in their differential diagnosis. Hopefully the term "ChikDenMaZika syndrome" will provide clinicians with a useful mnemonic tool that would aid in narrowing-down diagnosis when faced with arbovirallike disease symptoms such as fever, maculopapular rash, arthralgias, myalgias and non-purulent conjunctivitis (or conjunctival hyperemia). Such multi-agent targeted approach in clinical diagnostics should also be extrapolated to the laboratory bench by improving the usage of multiplex RT-PCR diagnostic platforms for arboviruses in returning travelers [36], as well as residents of endemic areas, given the increasing reported frequency of co-circulation of multiple arboviruses and its emerging threat in tropical regions [44].

\begin{abstract}
Author details
1 Department of Pathology and Laboratory Medicine, Hospital Internacional, Barquisimeto, Venezuela. ${ }^{2}$ Laboratory of Biochemistry, Instituto de Biomedicina/IVSS, Caracas, Venezuela. ${ }^{3}$ Colombian Collaborative Network on Zika (RECOLZIKA), Pereira, Risaralda, Colombia. ${ }^{4}$ Public Health and Infection Research Group, Faculty of Health Sciences, Universidad Tecnologica de Pereira, Pereira, Risaralda, Colombia. ${ }^{5}$ Organización Latinoamericana Para el Fomento de la Investigación en Salud (OLFIS), Bucaramanga, Santander, Colombia. ${ }^{6}$ Committee on Zoonoses and Haemorrhagic Fevers, Asociación Colombiana de Infectología (ACIN), Bogotá, DC, Colombia. ${ }^{7}$ Department of Biology, University of Florida, Gainesville, FL, USA. ${ }^{8}$ Infectious Diseases and Infection Control Research Group, Hospital Universitario de Sincelejo, Sincelejo, Sucre, Colombia. ${ }^{9}$ Programa del Doctorado de Medicina Tropical, Universidad del Atlántico, Barranquilla, Atlántico, Colombia.
\end{abstract}

\section{Competing interests}

The authors declare that they have no competing interests.

Received: 28 June 2016 Accepted: 8 July 2016

Published online: 22 July 2016

\section{References}

1. Alfaro-Toloza P, Clouet-Huerta DE, Rodriguez-Morales AJ. Chikungunya, the emerging migratory rheumatism. Lancet Infect Dis. 2015;15(5):510-2.

2. Sarmiento-Ospina A, Vasquez-Serna H, Jimenez-Canizales CE, VillamilGomez WE, Rodriguez-Morales AJ. Zika virus associated deaths in Colombia. Lancet Infectious Dis. 2016;16(5):523-4.

3. Rodriguez-Morales AJ, Villamil-Gomez WE, Franco-Paredes C. The arboviral burden of disease caused by co-circulation and co-infection of dengue, chikungunya and Zika in the Americas. Travel Med Infect Dis. 2016;14(3):177-9.

4. Rodriguez-Morales AJ, Paniz-Mondolfi AE. Venezuela: far from the path to dengue and chikungunya control. J Clin Virol. 2015;66:60-1.

5. Mattar S, Morales V, Cassab A, Rodriguez-Morales AJ. Effect of climate variables on dengue incidence in a tropical Caribbean municipality of Colombia, Cerete, 2003-2008. Int J Infect Dis. 2013;17(5):e358-9.

6. Herrera-Martinez AD, Rodriguez-Morales AJ. Potential influence of climate variability on dengue incidence registered in a western pediatric Hospital of Venezuela. Trop Biomed. 2010;27(2):280-6.

7. Zambrano LI, Sevilla C, Reyes-Garcia SZ, Sierra M, Kafati R, Rodriguez-Morales AJ, Mattar S. Potential impacts of climate variability on dengue hemorrhagic fever in Honduras, 2010. Trop Biomed. 2012;29(4):499-507.

8. Rodriguez-Morales AJ, Patino-Cadavid LJ, Lozada-Riascos CO, VillamilGomez WE. Mapping Zika in municipalities of one coastal department of Colombia (Sucre) using geographic information systems during the 2015-2016 outbreak: implications for public health and travel advice. Int J Infect Dis. 2016;48:70-2.
9. Rodriguez-Morales AJ. Zika and microcephaly in Latin America: An emerging threat for pregnant travelers? Travel Med Infect Dis. 2016;14(1):5-6.

10. Rodriguez-Morales AJ, Bedoya-Arias JE, Ramirez-Jaramillo V, MontoyaArias CP, Guerrero-Matituy EA, Cardenas-Giraldo EV. Using geographic information system (GIS) to mapping and assess changes in transmission patterns of chikungunya fever in municipalities of the Coffee-Triangle region of Colombia during 2014-2015 outbreak: Implications for travel advice. Travel Med Infect Dis. 2016;14(1):62-5.

11. Rodriguez-Morales AJ, Cardenas-Giraldo EV, Montoya-Arias CP, Guerrero-Matituy EA, Bedoya-Arias JE, Ramirez-Jaramillo V, Villamil-Gomez WE. Mapping chikungunya fever in municipalities of one coastal department of Colombia (Sucre) using geographic information system (GIS) during 2014 outbreak: Implications for travel advice. Travel Med Infect Dis. 2015;13(3):256-8.

12. Rodriguez-Morales AJ, Garcia-Loaiza CJ, Galindo-Marquez ML, SabogalRoman JA, Marin-Loaiza S, Lozada-Riascos CO, Diaz-Quijano FA. Zika infection GIS-based mapping suggest high transmission activity in the border area of La Guajira, Colombia, a northeastern coast Caribbean department 2015-2016: Implications for public health, migration and travel. Travel Med Infect Dis. 2016;14(3):286-8.

13. Noel H, Rizzo C. Spread of chikungunya from the Caribbean to mainland Central and South America: a greater risk of spillover in Europe? Euro Surveill. 2014;19(28):20855.

14. McFarlane R, Becker N, Field H. Investigation of the climatic and environmental context of Hendra virus spillover events 1994-2010. PLoS One. 2011;6(12):e28374.

15. Plowright RK, Eby P, Hudson PJ, Smith IL, Westcott D, Bryden WL, Middleton D, Reid PA, McFarlane RA, Martin G, et al. Ecological dynamics of emerging bat virus spillover. Proc Biol Sci. 2015;282(1798):20142124.

16. Kreuder Johnson C, Hitchens PL, Smiley Evans T, Goldstein T, Thomas K, Clements A, Joly DO, Wolfe ND, Daszak P, Karesh WB, et al. Spillover and pandemic properties of zoonotic viruses with high host plasticity. Sci Rep. 2015:5:14830.

17. Rifakis PM, Benitez JA, De-la-Paz-Pineda J, Rodriguez-Morales AJ. Epizootics of yellow fever in Venezuela (2004-2005): an emerging zoonotic disease. Ann NY Acad Sci. 2006;1081:57-60.

18. Villamil-Gomez WE, Gonzalez-Camargo O, Rodriguez-Ayubi J, ZapataSerpa D, Rodriguez-Morales AJ. Dengue, chikungunya and Zika co-infection in a patient from Colombia. J Infect Public Health. 2016. doi:10.1016/j.jiph.2015.12.002

19. Patino-Barbosa AM, Bedoya-Arias JE, Cardona-Ospina JA, RodriguezMorales AJ. Bibliometric assessment of the scientific production of literature regarding Mayaro. J Infect Public Health. 2016;9(4):532-4.

20. Munoz M, Navarro JC. Mayaro: a re-emerging Arbovirus in Venezuela and Latin America. Biomedica. 2012;32(2):286-302.

21. Auguste AJ, Liria J, Forrester NL, Giambalvo D, Moncada M, Long KC, Moron D, de Manzione N, Tesh RB, Halsey ES, et al. evolutionary and ecological characterization of Mayaro virus strains isolated during an Outbreak, Venezuela, 2010. Emerg Infect Dis. 2015;21(10):1742-50.

22. Navarro JC, Giambalvo D, Hernandez R, Auguste AJ, Tesh RB, Weaver SC, Montanez H, Liria J, Lima A, Travassos da Rosa JF, et al. Isolation of Madre de Dios Virus (Orthobunyavirus; Bunyaviridae), an Oropouche Virus Species Reassortant, from a Monkey in Venezuela. Am J Trop Med Hyg. 2016. doi:10.4269/ajtmh.15-0679.

23. Patino-Barbosa AM, Medina I, Gil-Restrepo AF, Rodriguez-Morales AJ. Zika: another sexually transmitted infection? Sex Transm Infect. 2015;91(5):359.

24. Arzuza-Ortega L, Polo A, Perez-Tatis G, Lopez-Garcia H, Parra E, PardoHerrera LC, Rico-Turca AM, Villamil-Gomez W, Rodriguez-Morales AJ. Fatal sickle cell disease and zika virus infection in girl from Colombia. Emerg Infect Dis. 2016;22(5):925-7.

25. Rodriguez-Morales AJ. Dengue and chikungunya were not enough: now also zika arrived. Arch Med. 2015;11(2):e3.

26. Villamil-Gomez W, Alba-Silvera L, Menco-Ramos A, Gonzalez-Vergara A, Molinares-Palacios T, Barrios-Corrales M, Rodriguez-Morales AJ. Congenital chikungunya virus infection in Sincelejo, Colombia: a case series. J Trop Pediatr. 2015;61(5):386-92.

27. Villamil-Gomez WE, Mendoza-Guete A, Villalobos E, Gonzalez-Arismendy E, Uribe-Garcia AM, Castellanos JE, Rodriguez-Morales AJ. Diagnosis, management and follow-up of pregnant women with Zika virus infection: a preliminary report of the ZIKERNCOL cohort study on Sincelejo, Colombia. Travel Med Infect Dis. 2016;14(2):155-8. 
28. Raut CG, Rao NM, Sinha DP, Hanumaiah H, Manjunatha MJ. Chikungunya, dengue, and malaria co-infection after travel to Nigeria, India. Emerg Infect Dis. 2015;21(5):908-9.

29. Parreira R, Centeno-Lima S, Lopes A, Portugal-Calisto D, Constantino A, Nina J. Dengue virus serotype 4 and chikungunya virus coinfection in a traveller returning from Luanda, Angola, January 2014. Euro Surveill. 2014;19(10). doi:10.2807/1560-7917.ES2014.19.10.20730.

30. Ling Y, Chen J, Huang Q, Hu Y, Zhu A, Ye S, Xu L, Lu H. Yellow fever in a worker returning to China from Angola, March 2016. Emerg Infect Dis. 2016;22(7):1317-8.

31. Lednicky J, BeauDeRochars VM, ElBadry M, Loeb J, Telisma T, Chavannes S, Anilis G, Cella E, Ciccozzi M, Rashid M, et al. Zika Virus Outbreak in Haiti in 2014: Molecular and Clinical Data. PLoS Negl Trop Dis. 2016;10(4):e0004687.

32. Andrade EH, Figueiredo LB, Vilela AP, Rosa JC, Oliveira JG, Zibaoui HM, Araujo VE, Miranda DP, Ferreira PC, Abrahao JS, et al. Spatial-temporal cocirculation of dengue virus 1, 2, 3, and 4 associated with coinfection cases in a hyperendemic area of Brazil: A 4-week survey. Am J Trop Med Hyg. 2016;94(5):1080-4.

33. Dupont-Rouzeyrol M, O'Connor O, Calvez E, Daures M, John M, Grangeon JP, Gourinat AC. Co-infection with Zika and dengue viruses in 2 patients, New Caledonia, 2014. Emerg Infect Dis. 2015;21(2):381-2.

34. Barreiro P. First case of zika virus infection in a HIV+ patient. AIDS reviews. 2016;18(2):112.

35. Calvet GA, Filippis AM, Mendonca MC, Sequeira PC, Siqueira AM, Veloso VG, Nogueira RM, Brasil P. First detection of autochthonous Zika virus transmission in a HIV-infected patient in Rio de Janeiro, Brazil. J Clin Virol. 2016;74:1-3.

36. Waggoner JJ, Gresh L, Mohamed-Hadley A, Ballesteros G, Davila MJ, Tellez Y, Sahoo MK, Balmaseda A, Harris E, Pinsky BA. Single-reaction multiplex reverse transcription pcr for detection of zika, Chikungunya, and dengue viruses. Emerg Infect Dis. 2016;22(7):1295-7.
37. Kasper DL, Fauci A, Hauser S, Longo D, Larry Jameson J, Loscalzo J. Harrison's principles of internal medicine. 19th edn. McGraw-Hill: New York; 2015. ISBN 978-0071802154.

38. Rodriguez-Morales AJ, Sanchez E, Vargas M, Piccolo C, Colina R, Arria $\mathrm{M}$, Franco-Paredes C. Is anemia in Plasmodium vivax malaria more frequent and severe than in Plasmodium falciparum? Am J Med. 2006;119(11):e9-10.

39. Rifakis PM, Hernandez O, Fernandez CT, Rodriguez-Morales AJ, Von A, Franco-Paredes C. Atypical Plasmodium vivax malaria in a traveler: bilateral hydronephrosis, severe thrombocytopenia, and hypotension. J Travel Med. 2008;15(2):119-21.

40. Benitez JA, Araujo B, Contreras K, Rivas M, Ramirez P, Guerra W, Calderon N, AscasoTerren C, Barrera R, Rodriguez-Morales AJ. Urban outbreak of acute orally acquired Chagas disease in Tachira, Venezuela. Journal of infection in developing countries. 2013;7(8):638-41.

41. Villamil-Gomez WE, Echeverria LE, Ayala MS, Munoz L, Mejia L, Eyes-Escalante M, Venegas-Hermosilla J, Rodriguez-Morales AJ. Orally transmitted acute Chagas disease in domestic travelers in Colombia. J Infect Public Health. 2016. doi:10.1016/j.jiph.2016.05.002.

42. Gomez PC, Mantilla HJ, Rodriguez-Morales AJ. Fatal chagas disease among solid-organ transplant recipients in Colombia. Open Forum Infect Dis. 2014;1(1):ofu032.

43. Rodriguez-Morales AJ, Benitez JA, Tellez I, Franco-Paredes C. Chagas disease screening among Latin American immigrants in non-endemic settings. Travel Med Infect Dis. 2008;6(3):162-3.

44. Rodriguez-Morales AJ. Zika: the new arbovirus threat for Latin America. J Infect Dev Ctries. 2015;9(6):684-5.

\section{Submit your next manuscript to BioMed Central and we will help you at every step:}

- We accept pre-submission inquiries

- Our selector tool helps you to find the most relevant journal

- We provide round the clock customer support

- Convenient online submission

- Thorough peer review

- Inclusion in PubMed and all major indexing services

- Maximum visibility for your research

Submit your manuscript at www.biomedcentral.com/submit
() Biomed Central 